\title{
IMPLEMENTASI MODEL PEMBELAJARAN KOOPERATIF TIPE TEAM \\ GAMES TOURNAMENT (TGT) BERBANTU MEDIA PEMBELAJARAN PERMAINAN TRADISIONAL CUBLAK-CUBLAK SUWENG UNTUK MENINGKATKAN MOTIVASI BELAJAR DALAM PEMBELAJARAN MATEMATIKA SISWA KELAS IV SD BINA TUNAS
}

\author{
Oktavia Dwi Wuyung Sari \\ Program Studi Pendidikan Guru Sekolah Dasar, Universitas Dwijendra \\ e-mail : oktaviadwiws@gmail.com \\ Ni Luh Gede Karang Widiastuti \\ Program Studi Pendidikan Guru Sekolah Dasar, Universitas Dwijendra \\ e-mail: karangwidhi@gmail.com
}

\begin{abstract}
Abstrak
Penelitian ini bertujuan untuk meningkatkan motivasi belajar dalam pembelajaran matematika melalui implementasi kooperatif tipe teams games tournament (TGT) berbantu media pembelajaran permainan tradisional cublak-cublak suweng. Penelitian ini merupakan Penelitian Tindakan Kelas yang dilaksanakan secara kolaboratif antara guru dengan peneliti pada mata pelajaran matematika. Subjek dalam penelitian ini adalah siswa kelas IV SD Bina Tunas yang berjumlah 6 siswa yang terdiri dari 3 siswa perempuan dan 3 siswa laki-laki. Metode pengumpulan data dalam penelitian ini menggunakan observasi dan dokumentasi. Instrumen penelitian yang digunakan yaitu lembar observasi dan dokumentasi. Teknik analisis data yang digunakan dalam penelitian ini adalah analisis data deskriptif kuantitatif. Berdasarkan hasil penelitian dapat disimpulkan bahwa model pembelajaran kooperatif tipe teams games tournament (TGT) berbantu media pembelajaran permainan tradisional cublak-cublak suweng untuk meningkatkan motivasi belajar dalam pembelajaran matematika kelas IV SD Bina Tunas. Hal ini ditunjukkan dengan adanya peningkatan persentase skor rata-rata motivasi belajar matematika sebesar pada siklus I sebesar $69,66 \%$ dan pada siklus II sebesar $84,83 \%$. Terjadi peningkatan dari siklus I ke siklus II sebesar $15,17 \%$. Hasil analisis data siklus II menunjukkan bahwa skor tersebut sudah mencapai indikator keberhasilan yang ditentukan yaitu minimal tinggi. Terdapat 5 indikator dengan 4 deskripsi motivasi belajar dalam penelitian ini dan kelima indikator tersebut telah mencapai indikator keberhasilan yang ditentukan minimal tinggi.
\end{abstract}

Kata Kunci: Teams Games Tournament (TGT), Media Pembelajaran Permainan Tradisional Cublak-cublak Suweng, Motivasi Belajar Matematika

\begin{abstract}
This research aimed to increase learning motivation in mathematic learning through implement a cooperative learning model, the type of teams games tournament (TGT) was assisted by the learning media of cublak-cublak suweng traditional games. Assisted by traditional learning media cublak-cublak suweng in learning motivation for fourth grade mathematics learning at SD Bina Tunas. This research was a classroom action research which was carried out collaboratively between teachers and researchers in mathematics. The subjects in this research were the fourth grade students of SD Bina Tunas, totaling 6 students consisting of 3 female students and 3 male students. Data collection methods in this research using observation and documentation. The research instrument used was the observation sheet and documentation. The data analysis technique used in this research was descriptive quantitative data analysis. Based on the results of the research, it was concluded that the cooperative learning model of the Teams Games Tournament (TGT) type was assisted by the learning media of cublak-cublak suweng traditional games to increase learning motivation in the fourth grade mathematics learning of SD Bina Tunas.
\end{abstract}


It was indicated by an increase in the percentage of the average score of learning motivation for mathematics in the first cycle of $69.66 \%$ and $84.83 \%$ in the second cycle. There was an increase from cycle I to cycle II of $15.17 \%$. The results of cycle II data analysis indicated that the score had reached the specified success indicator, which was at least high. There were 5 indicators with 4 descriptions of learning motivation in this research and the five indicators had reached the specified minimum high success indicator.

Keywords: Teams Games Tournament (TGT), Learning Media for Traditional Games Cublakcublak Suweng, Motivation to Learn Mathematics

\section{PENDAHULUAN}

Kurikulum 2013 (K-13) adalah

kurikulum yang berlaku dalam Sistem Pendidikan Indonesia. Kurikulum ini merupakan kurikulum tetap yang diterapkan oleh pemerintah untuk menggantikan Kurikulum-2006 atau yang sering disebut sebagai Kurikulum Tingkat Satuan Pendidikan (KTSP) yang telah berlaku selama kurang lebih 6 tahun. Kurikulum 2013 memiliki tiga aspek penilaian, yaitu aspek pengetahuan, aspek keterampilan, aspek sikap dan perilaku. Dalam tujuan kurikulum 2013, siswa dituntut untuk berpikir lebih kreatif, inovatif, cepat dan tanggap dan selain itu dalam kurikulum 2013 siswa dilatih untuk menumbuhkan keberanian dalam dirinya. Siswa akan dilatih kemampuan berlogika dalam memecahkan suatu permasalahan. Sesuai dengan kurikulum 2013 tujuan pembelajaran matematika menekankan pada dimensi pedagogik modern dalam pembelajaran, yaitu menggunakan pendekatan ilmiah (scientific). Dalam pembelajaran matematika kegiatan yang dilakukan agar pembelajaran bermakna yaitu mengamati, menanya, mencoba, menalar, menyaji, dan mencipta (Kemendikbud, 2013).

Pada mata pelajaran matematika yang diajarkan di SD dianggap mata pelajaran yang sulit bahkan menjadi momok yang ditakuti dalam setiap kegiatan belajar mengajar. Ditambah lagi dengan guru yang hanya menggunakan model pembelajaran konvensional dan kurang memanfaatkan media pembelajaran yang sudah ada. Sehingga membuat siswa cepat merasa bosan saat kegiatan pembelajaran berlangsung. Hal ini juga tercermin pada kenyataan dilapangan, guru dikelas masih lebih banyak menggunakan metode ceramah atau metode tanya jawab dengan siswa tanpa menggunakan media pembelajaran yang disediakan oleh sekolah maupun media yang disiapkan oleh guru itu sendiri. Dari metode yang biasa digunakan oleh guru dikelas dapat menimbulkan kecenderungan bosan terhadap pelajaran yang diajarkan di kelas. Akhirnya apa yang diharapkan dari prestasi belajar matematika ternyata masih jauh dari harapan, ini juga berdampak pada rendahnya motivasi belajar siswa dalam belajar matematika. Dapat dilihat dari nilai ulangan matematika yang hanya berkisar antara 60- 
75 saja siswa kelas IV SD Bina Tunas pada mata pelajaran matematika pada tahun ajaran 2019-2020 menunjukkan belum optimal karena kurangnya motivasi belajar siswa pada mata pelajaran matematika. Oleh karena itu, diperlukan suatu model pembelajaran yang menarik, efektif, dan relevan pada mata pelajaran matematika.

Salah satu upaya yang dapat ditempuh oleh guru dalam rangka memperbaiki proses pembelajaran matematika dengan menggunakan model pembelajaran tipe Team Games Tournament (TGT). Model pembelajaran tipe Team Games Tournament (TGT) adalah salah satu tipe model pembelajaran yang mudah diterapkan, melibatkan aktivitas seluruh siswa tanpa harus ada perbedaan status, melibatkan peran siswa sebagai tutor sebaya dan mengandung unsur permainan dan penguatan.

$\begin{array}{rrrr} & \text { Kegiatan } & \text { belajar } & \text { dengan } \\ \text { permainan } & \text { yang } & \text { dirancang } & \text { dalam }\end{array}$ pembelajaran tipe TGT memungkinkan siswa dapat belajar lebih rileks, disamping membutuhkan tanggung jawab, percaya diri, menghargai sesama, disiplin, kooperatif, kerjasama dan keterlibatan belajar seluruh siswa. Hal ini didukung pada penelitian relevan yang dilakukan oleh Abdul Gapur pada tahun 2013 tentang "Meningkatkan Motivasi Belajar Murid melalui Metode Teams Games Tournament (TGT) Mata Pelajaran Matematika Kelas VI Madrasah Ibtidaiyah Azzahiddin Pekanbaru" analisis penelitian menyatakan bahwa penerapan model pembelajaran TGT dapat meningkatkan motivasi belajar siswa.

Selain model pembelajaran, penggunaan media pembelajaran berbasis budaya dalam pembelajaran matematika merupakan salah satu inovasi dalam menghilangkan anggapan bahwa matematika itu sulit sekaligus mengenalkan budaya yang belum banyak diketahui peserta didik. Menurut Hamalik (dalam Arsyad, 2013:19) mengemukakan bahwa penerapan media pembelajaran dalam proses pembelajaran dapat membangkitkan keinginan dan motivasi belajar siswa yang baru. Selain itu, penggunaan media pembelajaran dapat membantu memudahkan guru dalam menyampaikan materi serta memudahkan siswa dalam menangkap materi yang telah dijelaskan, yaitu dengan menggunakan media permainan tradisional cublak-cublak suweng.

Cublak-cublak Suweng adalah
sebuah
dinyanyikan untuk mengiringi sebuah permainan anak. Cublak-cublak suweng merupakan permainan tradisional yang berasal dari Jawa Tengah yang sering dimainkan oleh sekelompok anak perempuan antara 3 orang atau lebih (Aisyah, 2014). Selain itu permainan cublakcublak suweng juga memiliki nilai-nilai yang baik untuk tumbuh kembang siswa. Nilai yang terkandung meliputi, nilai tanggung jawab, nilai kewaspadaan, nilai 
kejujuran, nilai keberanian dan lain sebagainya.

Media pembelajaran permainan tradisional yang dimodifikasi dalam model pembelajaran pada pembelajaran matematika sebagai pemotivasi siswa dalam belajar dan diharapkan memalui media pembelajaran ini siswa akan lebih senang dan lebih tertarik akan belajar mata pelajaran matematika dan siswa tidak lagi menganggap matematika adalah momok yang perlu ditakuti. Terlebih lagi kita sebagai pengajar dapat memperkenalkan budaya Indonesia pada siswa sekolah dasar yang jaman sekarang permainan tradisional mulai tidak digemari.

Berdasarkan uraian yang telah dipaparkan diatas, penulis bermaksud untuk mengadakan penelitian dengan judul “ Impelementasi Model Pembelajarn Kooperatif Tipe Team Games Tournament (TGT) Berbantu Media Pembelajaran Permainan Tradisional Cublak-cublak Suweng Untuk Meningkatkan Motivasi Belajar Dalam Pembelajaran Matematika Siswa Kelas IV SD Bina Tunas"

Berdasarkan latar belakang masalah diatas maka perumusan masalah penelitian ini adalah apakah implementasi model pembelajaran kooperatif tipe Team Games Tournament (TGT) berbantu media pembelajaran permainan tradisional cublakcublak suweng dapat meningkatkan motivasi belajar dalam pembelajaran matematika siswa kelas IV SD Bina Tunas? Tujuan penelitian tindakan kelas ini adalah untuk mengetahui implementasi model pembelajaran kooperatif tipe Team Games Tournament (TGT) berbantu media pembelajaran permainan tradisional cublakcublak suweng dalam motivasi belajar dalam pembelajaran matematika siswa kelas IV SD Bina Tunas.

\section{METODE}

Penelitian implementasi model pembelajaran kooperatf tipe team games tournament (TGT) berbantu media pembelajaran tradisional cublak cublak suweng untuk meningkatkan motivasi belajar dalam pembelajaran nmatematika siswa kelas IV SD Bina Tunas ini merupakan jenis penelitian tindakan kelas (PTK). Penelitian tindakan kelas (PTK) ini bertujuan untuk mengatasi suatu permasalahan atau memperbaiki suatu pembelajaran di dalam kelas. Penelitian ini dilakukan 2 siklus, setiap siklus dilakukan dalam 3 kali pertemuan. Peneliti menyusun tahapan-tahapan yang dilalui dalam penelitian tindakan kelas, yaitu: perencanaan / persiapan tindakan, pelaksanaan tindakan, observasi dan refleksi.

Subjek dalam penelitian ini adalah seluruh siswa kelas IV SD Bina Tunas, tahun pelajaran 2019/2020 berjumlah 6 siswa yang terdiri dari 3 siswa laki-laki dan 3 siswa perempuan. Penelitian tindakan kelas ini dilaksanakan pada siswa kelas IV di SD Bina Tunas dalam pelajaran 
matematika pada materi pokok data stastika. Pemilihan kelas IV SD Bina Tunas, menjadi tempat penelitian karena siswa kelas IV memiliki motivasi belajar siswa rendah di dalam kelas, guru masih kurang dalam menggunakan media pembelajaran dan belum menerapkan model dan media pembelajaran yang bervariasi dan peneliti sudah mengenal siswa pada saat PPL di SD Bina Tunas.

$\begin{array}{ccc}\text { Objek } & \text { penelitian } & \text { ini adalah } \\ \text { Implementasi } & \text { Model } & \text { Pembelajaran }\end{array}$
Kooperatif Tipe Team Games Tournament (TGT) Berbantu Media Pembelajaran Permainan Tradisional Cublak-cublak Suweng untuk Meningkatkan Motivasi Belajar Dalam Pembelajaran Matematika Kelas IV SD Bina Tunas. Waktu penelitian dilaksanakan pada bulan : April 2020, siklus I dilaksanakan 13 April 2020 sedangkan siklus II dilaksanakan 20 April 2020 dan telah disesuaikan dengan waktu efektif pada kalender pendidikan yang berlaku di sekolah bersangkutan.

Adapun metode pengumpulan data yang digunakan dalam penelitian ini adalah teknik non tes. Data motivasi belajar dikumpulkan melalui teknik non tes yaitu dilakukan pengamatan atau observasi dengan menggunakan instrumen lembar observasi. Lembar observasi yang digunakan dalam penelitian ini adalah jenis observasi terstruktur yakni menurut Kunandar (2013:277) yang terdiri dari 5 indikator.
Data yang dikumpulkan dalam penelitian ini dianalisis dengan menggunakan analisis deskriptif kuantitatif. Analisis data pada siswa mengenai motivasi belajar dilakukan melalui kegiatan observasi, yang datanya kemudian dianalisis dengan cara berikut. Menentukan motivasi belajar dengan menggunakan rata-rata motivasi siswa digunakan rumus sebagai berikut.

$$
\mathrm{M}=\frac{\sum X}{N}
$$

Keterangan:

$$
\begin{aligned}
\mathrm{M}= & \text { Skor rata-rata motivasi siswa } \\
\Sigma X= & \text { Jumlah skor motivasi } \\
N \quad= & \text { Banyaknya siswa } \\
& \text { (dalam Agung, 2014) }
\end{aligned}
$$

Menentukan persentase motivasinya digunakan rumus sebagai berikut.

$$
\mathrm{P}=\frac{\mathrm{M}}{\mathrm{SMI}} \times 100 \%
$$

Keterangan:

$$
\begin{aligned}
& \mathrm{P}=\text { Persentase aktivitas belajar } \\
& \mathrm{M}=\text { Rata-rata } \\
& \mathrm{SMI}=\text { Skor Maksimal Ideal }
\end{aligned}
$$

Menentukan persentase rata-rata motivasi belajar siswa setiap siklus dengan rumus:

Persentase rata-rata motivasi belajar siswa setiap siklus:

Jumlah persentase motivasi belajar siswa banyak pertemuan 
Untuk mengetahui tingkat ketercapaian motivasi belajar digunakan konversi penilaian acuan patokan (PAP) skala lima tingkatan motivasi belajar dapat menggunakan pedoman konversi PAP skala lima dilihat pada tabel 1 .

Tabel 1. Pedoman Konversi PAP Skala Lima Tentang Motivasi Belajar

$$
\begin{aligned}
& \text { (dalam Agung, 2014) } \\
& \text { Adapun indikator keberhasilan }
\end{aligned}
$$

yang digunakan dalam penelitian ini yaitu apabila persentase rata-rata motivasi belajar siswa minimal berada pada kriteria tinggi maka penelitian ini dikatakan berhasil. Apabila indikator keberhasilan telah tercapai maka penelitian ini dapat dihentikan.

\section{HASIL PENELITIAN DAN PEMBAHASAN}

Data yang dikumpulkan dalam penelitian ini yaitu data mengenai motivasi belajar matematika siswa kelas IV SD Bina
Tunas yang berjumlah 6 orang yang terdiri dari 3 laki-laki dan3 perempuan. Adapun hasil observasi awal ini menjadi acuan perencanaan tindakan. Berikut tabel kegiatan observasi sebelum pelaksanaan tindakan:

\begin{tabular}{|c|c|c|}
\hline No & Waktu & Kegiatan \\
\hline 1. & $\begin{array}{c}\text { Rabu,23 } \\
\text { Oktober } \\
2019\end{array}$ & 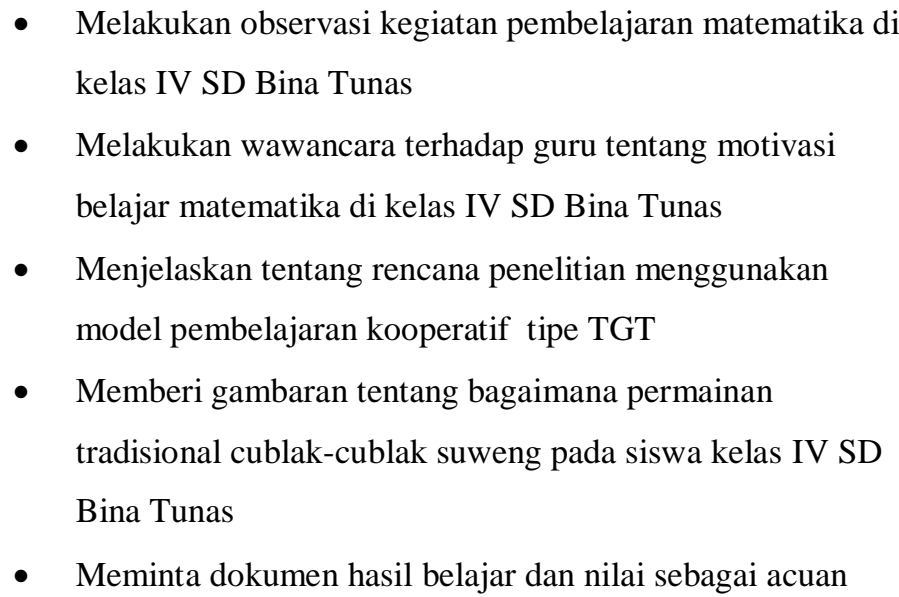 \\
\hline
\end{tabular}

Tabel 2. Kegiatan Pengamatan Kondisi Awal atau Sebelum Tindakan 


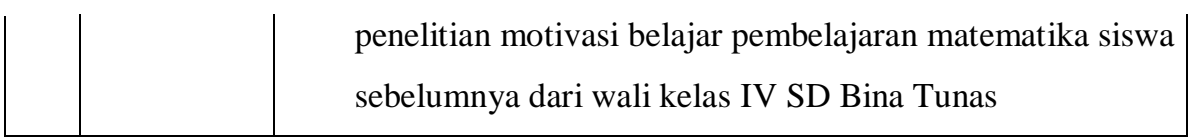

Berdasarkan hasil observasi yang dilakukan pada proses motivasi belajar matematika di kelas IV SD Bina Tunas diperoleh hasil bahwa metode pembelajaran yang digunakan guru adalah metode ceramah dan tanya jawab, yaitu guru menjelaskan materi di depan kelas, siswa menghafalkan materi dan kemudian mengerjakan soal, pada saat proses belajar mengajar, siswa dan terlihat kurang termotivasi dalam mengikuti pelajaran. guru selalu membuka pelajaran dengan salam dan mengecek kehadiran siswa tanpa memberika apersepsi pembelajaran pada siswa, penyajian materi dilakukan guru dengan cara siswa diminta membaca buku paket. Guru lebih banyak duduk dari pada berdiri didepan kelas, sehingga banyak siswa yang kurang memperhatikan dan proses pembelajaran menjadi tidak kondusif. Untuk mengetahui motivasi belajar siswa, guru meminta siswa mengerjakan soal-soal dalam buku paket, dan setelah pembelajaran selesai, guru menutup pelajaran tanpa menyimpulkan pembelajaran dan memberikan pekerjaan rumah (PR).
Berdasarkan hasil observasi nilai awal dan wawancara kepada guru kelas 4, dapat diketahui bahwa motivasi belajar matematika siswa sebelum penelitian, di peroleh persentase rata-rata $60,22 \%$. Data ini selanjutnya menjadi bahan refleksi awal untuk memperbaiki proses pembelajaran melalui Penelitian Tindakan Kelas secara bersiklus yang terdiri dari perencanaan, observasi, pelaksanaan dan refleksisiklus I dengan siklus II dapat dilihat dari tabel berikut

Tabel 3. Peningkatan Persentase Ratarata Motivasi Belajar Siswa Prasiklus, Siklus I dengan Siklus II

\begin{tabular}{|c|c|c|}
\hline Variabel & $\begin{array}{c}\text { Persenta } \\
\text { se rata- } \\
\text { rata }\end{array}$ & Kriteria \\
\hline Prasiklus & $\mathbf{6 0 , 2 2 \%}$ & $\begin{array}{c}\text { Kurang } \\
\text { tinggi }\end{array}$ \\
\hline Siklus I & $\mathbf{6 9 , 6 6 \%}$ & $\begin{array}{c}\text { Cukup } \\
\text { tinggi }\end{array}$ \\
\hline Siklus II & $\mathbf{8 4 , 8 3 \%}$ & Tinggi \\
\hline
\end{tabular}

Data peningkatan motivasi belajar siswa dari pelaksanaan siklus I dan siklus II juga dapat dilihat pada grafik berikut. 


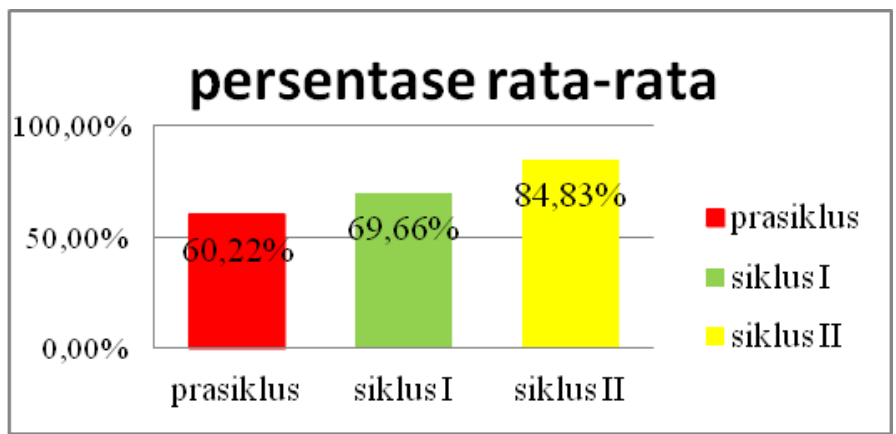

\section{Grafik 1. Peningkatan Persentase Rata-rata Motivasi Belajar Siswa Prasiklus, Siklus I}

\section{dengan Siklus II}

Berdasarkan tabel dan grafik diatas maka dapat dilihat terjadi peningkatan pada pemberian tindakan. Berdasarkan data yang diperoleh pada siklus II, kriteria yang diharapkan dalam penelitian ini sudah tercapai. Hal ini dapat dilihat pada tabel kriteria persentase rata-rata yang diharapkan yakni $84,83 \%$. Oleh karena itu penelitian ini dapat dikatakan berhasil atau penelitian dapat dihentikan karena sudah mencapai kreteria yang diharapkan. Motivasi belajar siswa kelas IV SD Bina Tunas pada refleksi awal atau sebelum tindakan masih rendah yakni 60,22\%. Hal ini ditunjukan oleh sebelum pelaksanaan tindakan pra siklus dalam observasi dan wawancara guru, diketahui bahwa SD Bina Tunas siswa masih kurang aktif yaitu siswa belum mencapai kriteria minimal tinggi. Rendahnya motivasi belajar disebabkan karena: proses pembelajaran masih didominasi oleh guru, siswa terlihat kurang aktif dan terlihat kurang termotivasi dalam mengikuti pelajaran, guru selalu membuka pelajaran dengan salam dan mengecek kehadiran siswa, penyajian materi dilakukan guru dengan cara siswa disuruh membaca buku paket dan terbatasnya media pembelajaran yang disajikan oleh guru. Guru lebih banyak duduk dari pada berdiri didepan kelas, sehingga banyak siswa yang kurang memperhatikan dan proses pembelajaran menjadi tidak kondusif, sehingga tingkat pemahaman siswa terhadap materi yang dipelajari juga rendah. Rendahnya tingkat pemahaman siswa terhadap materi yang dipelajari berdampak terhadap motivasi belajar yang diperoleh siswa. Berdasarkan permasalahan yang dikemukakan pada waktu refleksi awal peneliti berkolaborasi dengan guru untuk menerapkan model pembelajaran kooperatif tipe TGT berbantu media pembelajaran permainan tradisional cublak-cublak suweng pada mata pelajaran matematika.

Pada siklus I persentase rata-rata motivasi belajar siswa kelas IV SD Bina Tunas siswa mengalami peningkatan. Adapun persentase rata-rata $69,66 \%$ hasil tersebut belum dapat memenuhi indikator 
keberhasilan yang ditetapkan. Hal ini pada siklus I juga masih banyak ditemukan hambatan atau kekurangan dalam proses pembelajaran kekurangan-kekurangan tersebut Antara lain: 1) motivasi belajar siswa pada proses pembelajaran masih kurang, hal ini dikarenakan siswa belum terbiasa dengan model pembelajaran yang diterapkan, 2) siswa belum mampu belajar secara berkelompok dan bekerjasama dalam penyelesaian masalah. Hal ini disebabkan karena siswa belum mampu mengkoordinir kelompoknya dengan baik dan juga siswa belum mampu menghargai pendapat temannya dan kebanyakan siswa mengandalkan temannya yang pintar dalam kelompoknya, 3) masih perlu adanya media dan sumber belajar yang bervariatif untuk lebih menarik perhatian siswa dan menciptakan suasana yang interaktif dalam pembelajaran, dan 4) sebagian siswa masih belum mengenal permainan tradisional yang diajarkan. Untuk mengatasi kendala-kendala yang dihadapi dalam kegiatan pembelajaran pada siklus I, peneliti bersama dengan guru mendiskusikan perbaikan tindakan untuk selanjutnya diterapkan pada siklus II.

Perbaikan tindakan yang dilakukan, diantaranya sebagai berikut: 1) memberikan penjelasan mengenai langkah-langkah pembelajaran dan model pembelajaran yang akan dilaksanakan dengan jelas dan memberikan jeda waktu siswa untuk mengemukakan pertanyaan jika dirasa yang belum dimengerti untuk memastikan seluruh siswa memahami setiap langkah pembelajaran yang akan dilakukan, 2) siswa akan diarahkan untuk mencari kelompok untuk bekerjasama untuk mencapai kekompakan dalam kelompok, 3) menggunakan media dan menerapkan variasai pembelajaran yang variatif untuk menumbuhkan minat siswa serta interaksi dalam pembelajaran dan 4) guru menjelaskan dan mengilustrasikan dengan jelas tentang permainan tradisional cublakcublak suweng yang akan dimainkan.

Melalui refleksi pada siklus I, peneliti menyiapkan kembali skenario dalam RPP, setelah melakukan perbaikan proses pembelajaran pada siklus II aktivitas belajar siswa mengalami peningkatan. Hal ini ditunjukan dengan persentase rata-rata sebesar 84,83\%. Data tersebut dapat membuktikan implementasi model pembelajaran kooperatif tipe team game tournament berbantuan media pembelajaran permainan tradisional cublak-cublak suweng memang tepat digunakan untuk meningkatkan motivasi belajar di sekolah dasar, khususnya pada siswa kelas IV SD Bina Tunas.

Motivasi belajar siswa mengalami peningkatan karena siswa merasa tertarik mengimplementasikan model pembelajaran kooperatif tipe team games tournament (TGT) berbantuan media pembelajaran permainan tradisional cublak-cublak suweng karena menurut Hamalik (dalam Arsyad, 2013:19) mengemukanan bahwa penerapan 
media pembelajaran dalam proses pembelajaran dapat membangkitkan keinginan dan motivasi belajar siswa yang baru. Peningkatan tersebut sudah mencapai indikator keberhasilan yang ditentukan. Nilai siswa secara individu mengalami peningkatan yang cukup baik. Hal ini menjadikan skor persentase rata-rata $84,83 \%$ meningkat. Dengan adanya peningkatan tersebut, maka terbukti bahwa penerapan metode pembelajaran kooperatif tipe team games tournament (TGT) berbantu media pembelajaran permainan tradisional cublakcublak suweng mampu meningkatkan motivasi belajar siswa.

Hal ini didukung pada penelitian relevan yang dilakukan oleh penelitian yang dilakukan Penelitian lain, yaitu penelitian yang dilakukan oleh Ria Nurmala Dewi pada tahun 2016 tentang “ penerapan model pembelajan kooperatif tipe team games tournament (TGT) untuk meningkatkan aktivitas dan hasil belajar matematika siswa kelas Va SDN 10 Metro Timur" analisis penilitian menyatakan bahwa Penerapan model pembelajaran TGT dapat meningkatkan aktivitas belajar siswa. Pada siklus I nilai rata-rata aktivitas belajar siswa adalah 70,33, kemudian pada siklus II mendapat nilai 79,46. Peningkatan nilai ratarata aktivitas belajar siswa darisiklus I ke siklus II adalah 9,13. Persentase aktivitas belajar siswa pada siklus I sebesar $65,22 \%$ (katagori “Aktif') dan siklus II sebesar 86,96\% (katagori “Sangat Aktif”).
Persentase aktivitas belajar siswa secara klasikal dari siklus I ke siklus II mengalami peningkatan sebesar 21,74.

\section{PENUTUP}

Berdasarkan hasil penelitian dan pembahasan dapat disimpulkan bahwa implementasi model pembelajaran kooperatif tipe team games tournament (TGT) berbantu media pembelajaran permainan tradisional cublak-cublak suweng dapat meningkatkan motivasi belajar dalam pembelajaran matematika siswa kelas IV SD Bina Tunas yang dibuktikan dengan adanya peningkatan persentase rata-rata motivasi belajar matematika yang diambil melalui observasi dengan menggunakan lembar observasi. Skor persentase rata-rata motivasi belajar matematika pada siklus I yaitu sebesar 69,66\% dan pada siklus II 84,83\%. Terjadi peningkatan dari siklus I ke siklus II sebesar $15,17 \%$. Hasil rata-rata motivasi belajar matematika di siklus II menunjukkan bahwa skor tersebut sudah berada pada kriteria keberhasilan yang ditentukan yaitu minimal tinggi.

\section{DAFTAR PUSTAKA}

Agung, A.A. 2014. Metodoligi Penelitian Pendidikan. Yogyakarta: Aditya Media Publising.

Dewi, Ria Nurmala 2016. Penerapan Model Pembelajaran Team Game Tournament untuk Meningkatkan Aktivitas dan Hasil Belajar Matematika Siswa Kelas VA SDN 
10 Metro Timur. Universitas Lampung: Bandar Lampung.

Arsyad, Azhar. 2013. Media Pembelajaran. Jakarta : Rajawali Pers.

Fad, Aisyah. 2014. Kumpulan Permainan Anak Tradisional Indonesia. Jakarta: Cerdas Interaktif.

Kemendikbud, 2013. Kerangka Dasar dan Struktur Kurikulum 2013, Jakarta: Kemendikbud.

Kemendikbud. 2013. Permendikbud No. 67 tentang Kurikulum SD/MI. Kementerian Pendidikan dan Kebudayaan: Jakarta. Kemendikbud. 2016.

Kunandar. 2013. Langka Mudah Penelitian Tindakan Kelas (sebagai Pengembangan Profesi Guru). Jakarta: Raja Grafindo Persada.

Santika, I Gusti Ngurah. 2017. Kepala Sekolah Dalam Konsep Kepemimpinan Pendidikan: Suatu Kajian Teoritis. Widya Accarya. 7 (1).

Santika, I. G. N., Rindawan, I. K., \& Sujana, I. G. (2019). Memperkuat Pancasila Melalui Pergub No. 79 Tahun 2018 Dalam Menanggulangi Pengikisan Budaya Di Era Revolusi Industri 4.0. Prosiding Seminar Nasional Inobali 2019, 79, 981-990 